مجلة جامعة سبها للعلوم البحتة والتطبيقية

Sebha University Journal of Pure \& Applied Sciences

Journal homepage: www.sebhau.edu.ly/journal/index.php/jopas

\title{
Developing excellent architectural education for best practices in Libya
}

*Ozaer Zaed \& Zhen Chen

Department of Architecture, University of Strathclyde, Glasgow, UK

\section{Keywords:}

Architectural education

best practice

design practice

digital technology

Framework for Excellence

higher education curriculum

Libya

\begin{abstract}
A B S T R A C T
During the last decade there has been a rapid transition to digitisation in the construction sector across interconnected project stages, including design, construction, and operation. The research described in this paper aims to establish pathways to develop an excellent architectural education in Libya, in regard to relevant concerns on restructuring the curriculum to bridge the gap between educational output and professional requirements. An extensive literature review is adopted at the initial stage of the described research in order to establish a comprehensive understanding of architectural education in Libya. The findings from a preliminary literature review indicate that the absence of appropriate plans and obsolete curricula are critical issues in the current provision and further development of architectural education in Libya, and it is important for the continuous improvement of a nationwide architectural education curriculum that can strongly support students to develop relevant knowledge and skills to be prepared for their professional careers in helping to rebuild the country. In addition, it is crucial to establish a comprehensive architectural education programme at undergraduate level by adopting advanced digital technologies and enhancing collaborative learning for students to develop their competence with the appropriate body of knowledge and skills, which are important for their future careers and to increase architects' contribution to the development of economy, society, and the culture in Libya. It is expected that the described research can make a good contribution for professional practice enhancement in undergraduate architectural education in Libya, and to inform academics around the world with regard to the latest research and development for the best architectural education practice in Libya.
\end{abstract}

\section{التميزفي تطوير التعليم المعماري في ليبيا للحصول على أفضل الممارسات المعمارية}

Zhen Cheng عزير زايد زايد*

قسم الهندسة المعمارية، جامعة ستراتكلايد، غلاسكو، المملكة المتحدة

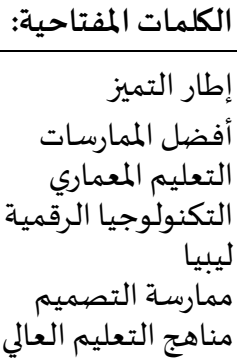

*Corresponding author:

E-mail addresses: ozaer.zaed@strath.ac.uk, (Z.Chen) z.chen@strath.ac.uk

خلال العقد الماضي كان هناك انتقال سريع إلى استخدام التقنيات الرقمية في قطاع البناء عبر مراحل عمل المشروع المختلفة، بما في ذلك التصميم والبناء والتشغيل. يهدف البحث الموصيوف في هذه الورقة إلى إنشاء مسارات لتطوير تعليم معماري ناجح في ليبيا، والي تحديد القضايا الهامة المتعلقة بإعادة هيكلة المناهج الدراسية

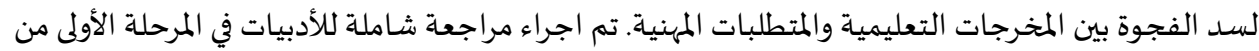
هدا البحث من أجل الحصيول على فهم شامل لوضيع التعليم المعماري في ليبيا. تشير النتائج الأولية المستخلصية من مراجعة الأدبيات إلى أن غياب الخطط الدراسية المناسبة والمناهج القديمة من اهم القضايا التي تعيق تطور

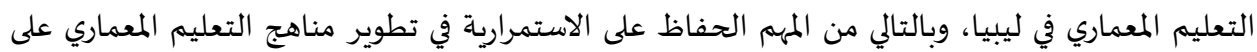

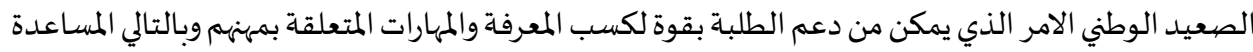

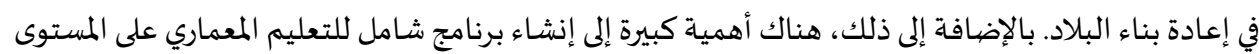
الجامعي من خلال اعتماد التقنيات الرقمية المتقدمة وتعزيز التعليم التعاوني بين الطلبة لتطوير كفاءاتههم

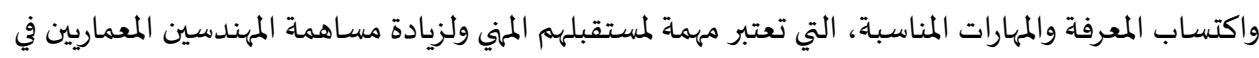
تنمية الاقتصاد والمجتمع والثقافة في ليبيا. من المتوقع أن يساهم هذا البحث في تعزيز الممارسات المهنية في

\footnotetext{
Article History : Received 13December 20 - Received in revised form 06 February 21 - Accepted 11 February 21
}

الملتخص 


$$
\text { التعليم المعماري في ليبيا للحصماري الجامعي في ليبيا، وإبلاغ الأكاديميين في جميع أنحاء العالم بأحدث الأبحاث المتعلقة بتطوير المضلى المبمارسات المعمارية. }
$$

\section{Introduction}

Investment in human capital is a critical issue in developing countries, particularly those with medium and high incomes like Libya. Investment in education is vital in offering an appropriate business environment to deliver excellent graduates entering the labour market with adequate knowledge and skills [1]. The correlation between the labour market and educational performance is essential for the individual outcomes of students themselves, who comprise a major part of the national population, and for national socio-economic and cultural development, making educational methods in all fields essential concerns, which must be understood by educators and curriculum designers. The construction industry is a major economic sector in itself, and it literally shapes national development [2]. It is increasingly evolving by the use of innovative technologies to facilitate communication and improve collaboration between all construction stakeholders, reducing waste and achieving streamlined and efficient processes. Such developments hinge on the development and improvement of education, which produces the professionals leading and driving such changes.

The Libyan higher education sector suffers from the absence of proper planning and procedures, due to numerous complex factors [3]. The result is a lack of qualified professionals in the Libyan construction industry particularly of the use of advanced technology [4]. In the last decade, this problem has gained more attention, and Libya's moribund system must be rapidly overhauled to keep pace with the technological advancement of global architectural and engineering programmes, and as a developing country, it stands to gain immensely in practical terms from more sophisticated educational solutions in these fields.

Professionals and students have often seen architectural practice and education as a challenging and demanding environment. This might be due to the training of architects needed many requirements include a variety of skillsets, marked by long working hours of design, layout, and modelling, which does not stop at the academic institutions but extends on a practice journey. Although some experts of the profession claim that, this is an appropriate path to success in architecture. This study explores new pathways and requirements generated for architectural curricula, which must be redefined in consistency with labour market needs. Architectural education seeks to prepare students to devise environmental and building solutions that are feasible and realistic for meeting and fulfilling users' needs and goals in the current and future market contexts. Consequently, it is essential to keep educational programmes flexible in choosing the appropriate teaching strategies, adopting new digital technologies methods, and enhancing collaborative learning, which provides students with effective learning and training.

\section{2. Literature review}

\subsection{Architectural practice in Libya}

The legacy system of Libyan architectural practices since the late $20^{\text {th }}$ century is one of quantity over quality, manifest in a sprawling and wasteful proliferation of modernist reinforced concrete buildings with no regard for vernacular traditions or environmental sustainability; the same ethos continued in projects since 2006, identified as a watershed due to Libya's rapprochement with the international community, with a focus on futuristic glass skyscrapers being planned [5]. While significant practical process has been tentative due to the civil war in 2011, there was a transition toward adopting new technology in recent years, without recognition that architecture is not just a collection of know-how and instruction in delivering and using software [6]. Today, architecture worldwide includes very diverse components, including training and research with diverse industries, such as economics, building efficiency, and energy analysis, relating to scientific and engineering studies, aside from the increasing centrality of environmental sustainability issues and vernacular cultural sensitivity.
The profession of architecture in Libya is continuously challenged by issues ranging from the quality of graduates, struggling for relevance in society, increasing competitiveness between practices for the few possibilities available, and disputes over the conventional position of the architect. Therefore, the development of successful pathways for architectural practice needs support from educational institutions and architectural associations, for instance, the Libyan Institute of Architecture (LIA), which was established in 2011 with the assistance of the Royal Institute of British Architects (RIBA) [7]. LIA must play an essential role in driving progress in Libyan architecture and the construction industry in general by restructuring architectural operations and creating coordination between educators and professionals.

\subsection{Architectural education in Libya}

The architectural education was introduced in Libyan universities during the late sixties of the $20^{\text {th }}$ century, as an extension of engineering programmes, with an annual academic curriculum for around 20 years without any amendments. The curriculum remains unstable since the semester system was introduced in the early 1980s [6]. The Libyan undergraduate architectural programmes offer two fundamental types of bachelor degrees; Architectural and Urban design and planning. These programmes are usually offered as majors in the same department of architecture. These programmes have been offered in various universities in Libya. However, each university offers these programmes depending on their respective course outlines and facilities.

Recently, there is much interesting in improving higher education in Libya. In addition, the Libyan Ministry of Education has put a plan forward to enhance and develop the educational system to raise its output efficiency, in line with the Sustainable Development Global vision 2030. The Ministry of Education also seeks to embed ICT into educational programmes in related subjects [8]. Therefore, various strategies and educational models need to find the best balance of diverse architectural, engineering, and construction disciplines [6]. Libyan architecture instructors should formulate shared goals and devise a blueprint of how to better integrate different disciplines in curriculum design and instruction. The curriculum needs to be developed to present relevant research, teaching, and training methods [9]. It is crucial to open conversations between participants and teachers in related industries issues concerning the stages of perception, information sharing, and learning from others.

\subsection{Challenges in undergraduate architectural education}

Libyan higher education, including architectural education, faces profound difficulties, due to intrinsic problems common to developing countries and particular socio-economic circumstances. Libya's universities face challenges in improving the standard of education facilities, increasing productivity in educational spending, and adopting modern learning and teaching approaches. These obstacles include providing proper training for teachers, providing qualifications, seeking methods to facilitate technological advancement, and developing skilled and technical infrastructure to cope with culture's implications [10]. Besides, a recent study conducted a survey to identify higher education difficulties in Libya, and it identified that the lack of appropriate planning is the biggest obstacle to education quality [3]. However, other significant factors include obsolete curricula, lack of collaborative learning among students, lack of the use of ICT in learning and teaching, lack of trained teachers, poor management, lack of fitted laboratories, and university libraries. Libya's on-going political instability further compounds these fundamental hindrances to educational development [3], [11], [12]. It is crucial to overcome these obstacles by developing comprehensive education programmes covering universities and labor market requirements and students' ambitions. 
Pedagogical stagnation has resulting in engineering and architectural education producing graduates without the necessary skills and training to address a number of social and economic development criteria, with the result that they do not meet the requirements of the local construction industry [1], [6]. This problem is further complicated by numerous social factors and pressures, particularly growing social demands on university education. Furthermore, the criteria for professional work are not explicitly assessed, and there is weak regulation. This is correlated with the excess of graduates in some disciplines, leading to severe shortages in others, particularly those related to new and emergent technologies. As a result, foreign workers are imported into several industries, particularly into the construction sector, which incurs additional costs for companies, and ultimately the national economy.

\section{Methodology}

The methodology implemented for this study is underpinned by a continuous extensive literature review, highlighting the lack of discussions of architectural education development in Libya. Consequently, this research seeks to provide a platform that surveys the status quo, as a starting point for further future researches to identify specific improvement routes.

The first step of the research included searching to identify relevant studies and collecting information about educational issues and curriculum development across the world and in Libya. A panoramic literature review was conducted to derive learning outcomes that can help develop a framework for excellence to facilitate developing architectural curriculum in Libyan universities. The critical evaluation was the second step to derive useful solutions to enhance curriculum design development for architectural education.

\section{4. Preliminary findings}

The study results are presented in three sections here concerning the identified best practice of the profession and education challenges of architects. These sections can be considered as the main points that architectural educators need to pay attention to for their architectural programmes.

\subsection{Digital technology}

As a result of digital technology globalisation, intellectual discussion has increased on what constitutes the whole body of architectural knowledge to be imparted to future professionals [13]. The digital revolution emphasised a need to review the current curriculum of architecture in the Libyan architectural schools with consideration of increased usage of computer content. The integration of digital technology can play a vital role in developing education, especially in higher education. ICT can achieve numerous educational goals with great efficiency, driving qualitative changes in teaching and learning quickly [14]. Integrating technology is more than just teaching basic programming skills and implementing in-class software programmes without requiring a separate computer class [15]. The integration of technology must occur in the educational system to facilitate the learning process in depth. There are four main learning elements that must be encouraged: (1) participation in groups, (2) active communication, (3) connection to real-world experts, and (4) regular interaction and feedback [16]. Efficient technology incorporation is accomplished when standard and transparent technology promote curricular objectives.

Libyan architectural schools have started to train students in the use of the most widely used and beneficial programmes, using professional practices such as computer-aided design (CAD). The incorporation of CAD increases the number of ideas and simulations encountered by students during simulation operation in synthesis activities [17]. The ability of students to gain expertise and design ideas for innovative architectural products was further strengthened by incorporating CAD in the design practices.

Architectural schools worldwide have been conducted several types of research that aim to identify the needs of professional practices. Building Information Modelling (BIM) is one of the main emerging technologies in the construction industry, and architecture educators have increasingly realised the need to introduce BIM in their programmes. As a result, different approaches have been used in teaching and learning BIM [18], [19]. Several studies revealed that the advantages of teaching BIM in architectural design studio include helping students obtain more understanding of building systems by using visualisation tools and multiple dimensions, for instance, threedimensional analyses assist in reviewing the building's design before starting to construct it [20], [21]. Due to the high global demand for using BIM technology, there is a need to teach it within architectural programmes in Libya [22], which can help to improve the competitiveness of architecture graduates in the national and international labour market.

\subsection{Collaborative learning}

Collaborative learning has a substantial impact on the progression of all engineering disciplines [15], but individual training remains the prevailing method in the architectural studio [23]. A critical review of the communication approach in architectural schools reveals that it can be improved by being more collaborative. The process of collaboration helps students communicate with peers from the same and other disciplines, to better understand building elements and needs for knowledge, arising from input and collaboration with other disciplines [24]. Improving the educational system is vital to achieving effective collaboration through architectural programmes redesign and the implementation of advanced solutions to enhance education standards. Architectural education is in great demand, and technology is being implemented to improve and maintain students' learning experience.

\subsection{Curriculum development strategy}

Curricular development is a methodical process in which courses with particular themes are planned and built. The curriculum must be effectively translated into learning practice with appropriate pedagogical methods matched to users' learning needs. Curriculum development must consider a wide array of stakeholders, including government, employers, training organisations, and educators, aside from students themselves. Pedagogical considerations include planning for available learning infrastructure, in terms of academic content, tools and ICT, educational methods, evaluation, and education facilities in general [10]. Due to the complicated and different tasks involved in curriculum execution, it is important to consider all aspects holistically throughout the entire program design. This involves identifying priorities and simultaneous creation of assessment and instruction to coordinate a particular curriculum in an organised way.

The curriculum can be conceptually divided into macro and micro levels [25]. The macro-level considers making the decision to offer and choose specific kinds of courses, the teaching approach and how it can be organised during the programme, and the time dedicated for each session. The micro-level concerns specific learning activities and content elements of courses [25], which can be considered as a stage of choice and organisation to improve the knowledge acquired by the student. It also deals with course materials, which may rely on curriculum design principles that are relevant to learning and teaching. It is also important to design a flexible curriculum to be periodically updated by suitable choose strategy, adopt advanced teaching approaches and include emerging technologies such as simulation tools, GIS, and BIM. Additionally, it is essential to provide architectural training, and short technical courses can effectively facilitate continuous learning.

The educational programme should meet the requirements of the construction industry and ambitions of students and their learning needs. Besides, the engineering curriculum plays a significant role in industrial development. The educational programme designer should seek inputs from a range of sources interested in creating the education programme [10]. It is essential to integrate the skills requested of modern architects into the architecture curriculum and equip architecture graduates with sufficient body of knowledge and skills to play a decisive role in their future jobs to contribute to the development of the construction sector, and thus wider socioeconomic development. 
Excellence architectural education and practice require an interactive integrated environment that accommodates various stakeholders include architectural schools, professional associations, and firms. These stakeholders can work together to develop national standards for architectural education and practice in Libya. The integration status among all diverse architectural education disciplines is also essential in developing a useful and reliable architectural education program. Moreover, there is a need to remain dynamic and responsive to the constant evolution of market requirements and available technological solutions, both in education and in the construction industry, which is working to develop substantial tributaries for the advancement of education and architectural practice. Figure 1 illustrates the conclusions from the study in a conceptual framework to present excellent architectural education for best practices in Libya.

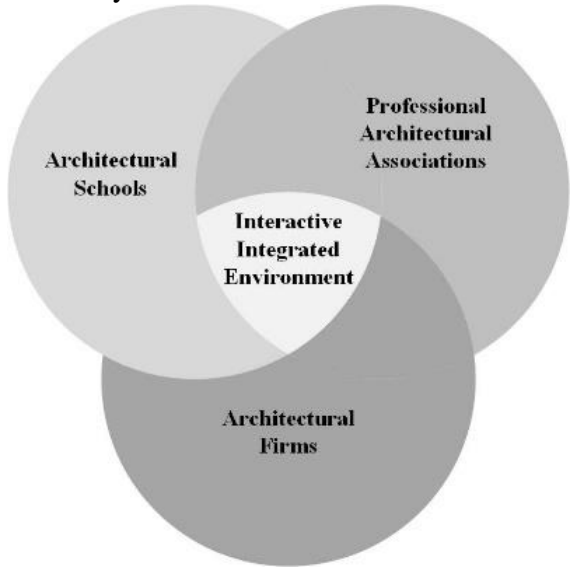

Figure 1. a conceptual framework for an excellent architectural education for best practice.

\section{Conclusion}

This paper describes pathways to develop excellent architectural education for best practices in Libya. This is based on preliminary research into current architectural curriculum issues and identified the main challenges facing the development of architectural education in Libya. A lack of proper planning, obsolete curricula and lack of using technology in learning and teaching are key barriers that prevent architectural education progress successfully. There is a need to provide sufficient financial support to develop universities infrastructure in relation to adopting digital technologies, laboratories, libraries, and train teachers.

Architectural education has a direct impact on improving the performance and quality of architectural practice. Thus, architectural education should present graduates with appropriate skills, knowledge, and abilities to deal with different design practice and managerial issues, which are significant for success in architectural practice. Consequently, the architectural curriculum must be kept up to date, and technical and methodical developments must be integrated. Collaboration between professionals and educators is key to producing the best results for business and higher education.

\section{Abbreviations}

BIM: Building Information Modeling

CAD: Computer-Aided Design

GIS: Geographic Information System

ICT: Information Communication Technology

\section{References}

[1]- A. Osman and D. Baldry, "Education mismatch of university graduates with labour market requirement in Libya construction sector," in 13th international postgraduate research conference, 2017, pp. 382-390.

[2]- A. Pekuri, H. Haapasalo, and M. Herrala, "Productivity and Performance Management-Managerial Practices in the Construction Industry," Int. J. Perform. Meas., vol. 1, no. 1, pp. 39-58, 2011.

[3]- D. Khalil and M. Halis, "Challenges Facing the Quality of
Education in the Libyan Higher Technical Colleges," Imp. J. Interdiscip. Res., vol. 3, no. 10, pp. 112-118, 2017.

[4]- A. S. Osman, "Educational and skills mismatch of University Graduates with Labour Market Requirements in Construction Sector in Libya," MPhil Thesis. University of Salford, 2019.

[5]- B. Azlitni, "The Libyan architectural features between tradition and modernization," Int. J. Hous. Sci. Its Appl., vol. 33, no. 3, pp. 137-148, 2009.

[6]- M. M. Mezughi, "Revamping Architectural Education and Practice in Libya," in Urban Planning and Architecture Design for Sustainable Development, 2015, pp. 1-7.

[7]- CID, "RIBA helps set up Libyan Institute of Architects - , Insight, - CID," Commercial Interiodesign, 2013. [Online]. Available: https://www.commercialinteriordesign.com/thoughts/ribahelps-set-libyan-counterpart. [Accessed: 22-Jan-2020].

[8]- Ministry of Education, "Ministry of Education Action Plan (2019)." Ministry of Education, Planning and Strategies Department, Tripoli, Libya, pp. 1-39, 2019.

[9]- A. Hoteit, "Architectural Education in the Arab World and Its Role in Facing the Contemporary Local and Regional Challenges," Can. Soc. Sci., pp. 1-7, 2016.

[10]- N. M. Triki, "Innovations and Curriculum Development for Technical and Engineering Education in Libya," Lit. Inf. Comput. Educ. J., vol. 7, no. 4, pp. 335-342, 2016, doi: 10.20533/licej.2040.2589.2016.0324.

[11]- A. M. Alzain, S. Clark, and G. Ireson, "Libyan higher education system, challenges and achievements," in 2014 IEEE 6th Conference on Engineering Education (ICEED), 2014, pp. 6772.

[12]- A. Rhema and I. Miliszewska, "Towards e-learning in higher education in Libya," Issues Informing Sci. Inf. Technol., vol. 7, no. 1, pp. 423-437, 2010.

[13]- O. Uwakonye, O. Alagbe, A. Oluwatayo, T. Alagbe, and G. Alalade, "Developing a New Framework for Integration and Teaching of Computer Aided Architectural Design (CAAD) in Nigerian Schools of Architecture," J. Educ. Pract., vol. 6, no. 3, pp. 17-26, 2015.

[14]- G. Kirkup and A. Kirkwood, "Information and communications technologies (ICT) in higher education teaching - A tale of gradualism rather than revolotion," in Learning, Media and Technology, 2005, vol. 30, no. 2, pp. 185-199, doi: 10.1080/17439880500093810.

[15]- T. Kenan, A. Elzawi, C. Pislaru, and M. Restoum, "A Study on the Impact of ICT on Collaborative Learning Processes in Libyan Higher Education," J. Internet Technol. Secur. Trans., vol. 3, no. 1, pp. 210-219, 2015.

[16]- F. S. Elshaikhi, "Integrating information technology in Libyan higher education." University of Kansas, 2015.

[17]- M. M. A. Elhardudi and K. Gokan, "Integrating CAAD into architectural education," M.Sc Thesis. İstanbul Kültür University Institute of Sciences \& Engineering, 2009.

[18]- O. Zaed and Z. Chen, "A methodological approach to excellence in BIM oriented architectural education," in Doctoral Workshop on Contemporary Advances in Research Methodology in Construction Management Workshop conveners: Glasgow Caledonian University, Glasgow, UK, 2019, no. November, pp. 1-3.

[19]- H. Abdirad and C. S. Dossick, "BIM curriculum design in architecture, engineering, and construction education: A systematic review," J. Inf. Technol. Constr., vol. 21, no. 17, pp. 250-271, 2016.

[20]- A. Abbas, Z. U. Din, and R. Farooqui, "Integration of BIM in Construction Management Education: An Overview of Pakistani Engineering Universities," in Procedia Engineering, 2016, vol. 145, pp. 151-157, doi: 10.1016/j.proeng.2016.04.034

[21]- M. B. Barison and E. T. Santos, "Review and analysis of current strategies for planning a BIM curriculum," in Proceedings of the CIB W78 2010: 27th International Conference, 2010, no. January 2010, pp. 1-10.

[22]- M. A. D. Saleh, "Barriers and Driving Factors for 
Implementing Building Information Modelling ( BIM ) in Libya," MSc Thesis. Eastern Mediterranean University, 2015.

[23]- P. Buchanan, "Whats wrong with architectural education? Almost everything," The architectural review, 2012. [Online]. Available: https://www.architectural-review.com/today/1989july-whats-wrong-with-architectural-education-almosteverything/8637977.article. [Accessed: 13-Jun-2020].

[24]- B. Becerik-Gerber, D. J. Gerber, and K. Ku, "The pace of technological innovation in architecture, engineering, and construction education: Integrating recent trends into the curricula," J. Inf. Technol. Constr., vol. 16, pp. 411-432, 2011.

[25]- J. Heywood, Engineering Education: Research and Development in Curriculum and Instruction. 2006. 